\section{Do poder FaMiliar e SUA EXTinÇÃo}

Adriana Brandini do Amparo* Heitor Luiz Ferreira do Amparo**

Poder familiar, segundo Washington de Barros Monteiro (2004), é o conjunto de obrigações, a cargo dos pais, no tocante à pessoa e aos bens dos filhos menores.

A denominação poder familiar foi adotada pelo novo Código Civil, em substituição à expressão pátrio poder, utilizada pelo Código de 1916 , harmonizando-se, assim, com a evolução das relações familiares ocorrida ao longo dos anos, que transferiu o poder exclusivo do pai para o poder conjunto dos pais, pois a ambos cumpre zelar pelo bem estar dos filhos e da família.

A lei civil em vigor enumera, no artigo 1634, uma série de deveres aos quais estão subordinados os pais, enquanto titulares do poder familiar, em relação a seus filhos, a saber: dirigir-lhes a criação e educação; tê-los em sua companhia e guarda; conceder-lhes ou negar-lhes consentimento para se casarem; nomearlhes tutor por testamento ou documento autêntico, se o outro dos pais não lhe sobreviver, ou o sobrevivo não puder exercer o poder familiar; representá-los até aos dezesseis anos, nos atos das vida civil, e assisti-los, após essa idade, nos atos em que forem partes, suprindo-lhes o consentimento; reclamá-los de quem ilegalmente os detenha; exigir que lhe prestem obediência, respeito e os serviços próprios de sua idade e condição.

No mesmo sentido, embora de forma mais objetiva, estabelece o Estatuto da Criança e do Adolescente (Lei 8069/1990), no seu artigo 22, o dever dos pais de sustento, guarda e educação dos filhos menores.

Esses deveres, contidos no Código Civil e no Estatuto da Criança e do Adolescente, guardam relação com o artigo 227 da Constituição Federal, que também consigna uma série de deveres atribuídos à família em beneficio dos filhos, enquanto menores ou adolescentes.

O poder familiar, que por sua natureza é indelegável, deve, portanto, ser exercido em absoluta sintonia com essas regras, voltadas, como frisado, basicamente ao interesse dos filhos e da família como entidade em si.

\section{*Advogada}

** Juiz de Direito em Araraquara e Professor de Direito Civil do Departamento de Ciências Jurídicas do Centro Universitário de Araraquara - UNIARA.
Não raro, esses deveres são descumpridos pelos pais, que ficam sujeitos a sanções de natureza civil e criminal

Entre as sanções de natureza civil, encontra-se a destituição do poder familiar, que consiste na sua interrupção, em face de condutas, por parte dos pais, consideradas graves.

Essa sanção, prevista no artigo 1638 do Código Civil, tem por escopo principal a proteção dos filhos e não a punição dos pais, como afirma Flávio Augusto Monteiro de Barros (2003).

A destituição do poder familiar permite, nesse passo, análise dos incisos do artigo 1638 da Lei Substantiva.

$\mathrm{Na}$ forma do artigo mencionado, portanto, perderá, por ato judicial o poder familiar o pai ou mãe que

I - castigar imoderadamente o filho (inciso I, do artigo 1638).

Estabelecendo punição apenas para o castigo imoderado, admitiu o legislador "a contrario sensu" que esse castigo possa ser aplicado pelos pais, porém moderadamente.

$\mathrm{O}$ castigo moderado, contudo, tem provocado divergências na doutrina, uns entendendo-o válido e outros não.

Denise Damo Comel (2003), discorrendo sobre o assunto afirma que "o castigo moderado é admitido como integrante do dever de correção dos pais, instrumento de garantia do respeito e obediência devidos. Todavia, o castigo sem moderação, levado a efeito com brutalidade, violência e agressividade, não pode ser admitido em hipótese alguma, porque não reverte benefício algum para o filho, ao contrário só resulta desproveito".

No mesmo sentido, Rui Ribeiro de Magalhães (2000), sustenta que "o castigo moderado, por vezes, além de necessário, mostra-se salutar, decorrendo do dever de criação e educação. O que não é aceitável é o castigo brutal, imoderado, nocivo à saúde e à integridade física do filho que possa comprometer o sentimento de afetividade recíproco".

Paulo Luiz Netto Lôbo (2002), por sua vez, afastando-se dessas opiniões, entende que o denominado castigo moderado traduz resquício do antigo pátrio poder e esclarece que: "Deixando de lado as discussões havidas em outros campos, sob o ponto de vista estritamente constitucional não há fundamento para o castigo físico ou psíquico, ainda que 'moderado', pois não deixa de consistir violência à integridade física do filho, que é direito fundamental, inviolável da pessoa, também oponível aos pais. O artigo 227 da Constituição determina que é dever da família colocar o filho (criança ou adolescente) a salvo de toda a violência. Todo castigo físico configura-se violência. Note-se que a Constituição (art. $5^{\circ}$, XLIX) assegura a integridade física do preso. Se assim é com o adulto, 
com maior razão não se pode admitir violação da integridade física da criança e do adolescente, sob o pretexto de castigá-lo".

O certo é que, embora existindo divergências doutrinárias, o castigo sem excessos é lícito; a lei pune o exagero, na intensidade dele ou na sua qualidade Mais severa será a pena imposta pelo juiz, em se apurando falta mais grave (Caio Mário da Silva Pereira, 2004).

O castigo imoderado pode ocorrer de diferentes modos. Podem caracterizálo, como acentua José Antônio de Paula Santos Neto (1994), castigos físicos como surras, espancamento, submissão à dor física, privação de alimentos exigência de serviços pesados e extremamente dificultosos, impróprios às condições do filho, dentre outros. Mas nem sempre a violência física é imprescindível para a configuração do castigo imoderado, pois a tortura psicológica também poderá, máxime em se tratando de crianças, configurar a hipótese.

\section{II - deixar o filho em abandono (inciso II, do artigo 1638).}

O abandono, como esclarece Silvio Rodrigues (2002), compreende o descaso intencional pela criação, educação e moralidade do filho.

Revela falta de aptidão para o exercício do poder familiar, tendo em vista que coloca o filho em situação de grave perigo, seja quanto à segurança e integridade pessoal, seja quanto à saúde e moralidade (Denise Damo Comel, 2003).

Pode o abandono caracterizar, ainda, as figuras penais previstas nos artigos 133 (abandono de incapaz), 134 (abandono de recém nascido), 244 (abandono material), 246 (abandono intelectual) e 247 (abandono moral) do Código Penal.

A falta ou carência de recursos financeiros, contudo, não constitui motivo suficiente para a perda ou suspensão do poder familiar, nos termos do artigo 23 do Estatuto da Criança e do Adolescente.

III - praticar atos contrários à moral e aos bons costumes (inciso III, do artigo 1638).

Todos os atos que de alguma forma comprometam a integridade moral da criança ou do adolescente tipificam a figura em exame, como por exemplo a utilização de drogas na presença dos filhos, ou o convívio com pessoas que vivem do tráfico de substâncias entorpecentes ou da prática de ilícitos penais

IV - incidir, reiteradamente, nas faltas previstas no artigo antecedente (inciso IV do artigo 1638).

A regra em questão, novidade inserida no novo Código Civil, deve ser analisada em sintonia com o artigo 1637 da mesma lei civil, e engloba de forma genérica a reincidência dos pais em descumprir os seus deveres.

A amplitude da regra, contudo, sugere o seu emprego de forma cautelosa, de forma a impedir a sua desnecessária ou injusta aplicação.
Além das sanções previstas no Código Civil, interessante se torna consignar que a perda do poder familiar pode ocorrer, ainda, como efeito de sentença condenatória, nos crimes dolosos sujeitos a pena de reclusão praticados contra filho, em conformidade com o contido no artigo 92, inciso II, do Código Penal.

A perda do poder familiar nas situações analisadas, por constituir severa punição aos pais somente deve ser aplicada em regular processo judicial, instaurado para esse fim, e após meticulosa apuração da violação dos deveres previstos na lei, sempre assegurando-se ao infrator a ampla defesa garantida pela Constituição Federal (artigo $5^{\circ}$, inciso LV).

\section{Referências bibliográficas:}

BARROS, Flávio Augusto Monteiro. Direito de família. Curso Preparatório para Concurso, 2003

COMEL, Denise Damo. Do poder familiar. São Paulo: Revista dos Tribunais, 2003

LÔBO, Paulo Luiz Netto. Direito de família e o novo código civil. 2.ed. Belo Horizonte: Del Rey, 2000.

MAGALHÃES, Rui Ribeiro. Instituições de direito de família. Leme: LED Editora de Direito, 2002.

MONTEIRO, Washington de Barros. Curso de direito civil. 37.ed. São Paulo: Saraiva, 2004. (v.2)

PEREIRA, Caio Mário da Silva. Instituições de direito civil. 14.ed. Rio de Janeiro: Forense, 2004. (v.5)

RODRIGUES, Silvio. Direito civil. 26.ed. São Paulo: Saraiva, 2001. (v.6)

SANTOS NETO, José Antônio de Paula. Do pátrio poder. São Paulo: Revista dos Tribunais, 1994

\section{Resumo:}

O poder familiar institui deveres aos pais, os quais, quando descumpridos, sujeitam os infratores a sanções, entre elas a sua destituição em regular processo judicial.

\section{Palavras-chave:}

Poder Familiar, Código Civil, Destituição.

\section{2}

